\title{
A CARBONIFEROUS (GONDWANA) FAUNA FROM SUBANDEAN BOLIVIA
}

\author{
A. G. ROCHA-GAMPOS*, R. G. DE CARVALHO*e A. J. AMOS**
}

ABSTRACT A small collection of marine fossils from three localities of the Taiguati and San Telmo(?) formations (Machareti Group) in southern subandean Bolivia (Parapeti River and Serrania de Balapuca) contains Levipustula levis Maxwell, Limipecten cf. L. burnettensis Maxwell, Cypricardinia(?) boliviana sp. nov., Stutchburia sp., Myonia sp. and Mourlonia balapucense sp. nov. The presence of Levipustula levis and the probable affinities of associated species indicate a Late Carboniferous (Namurian. -Westphalian) age for the fauna, its Gondwanic nature and link with similar assemblages from the Precordillera of Argentina and eastern Australia. This conclusion affects the prevailing paleogeographic interpretation of the area.

RESUMO Uma pequena coleção de fósseis da Formação Taiguati (Grupo Machareti) de três localidades da região Subandina da Bolívia contém Levipustula levis Maxwell, Limipecten cf. $L$. burnettensis Maxwell, Cypricardinia(?) boliviana sp. nov., Stutchburia sp., Myonia sp. e Mourlonia balapucense sp. nov.

A ocorrência de Levipustula levis e a afinidade das espécies associadas indicam uma idade neocarbonífera (namuriana-vestfaliana) para a fauna, sua natureza gonduânica e relações com assembléias similares da Pré-Cordilheira da Argentina e da Austrália ocidental. Essa conclusão tem implicações no entendimento da paleogeografia Subandina durante o Neopaleozóico.

INTRODUCTION Marine fossils are extremely rare in the Late Paleozoic strata of Subandean Bolivia usually known as "Gondwana". This clastic sedimentary sequence is up to $2,000 \mathrm{~m}$ thick and composed of sandstones and diamictites, plus silty and shaley units. It extends along the entire Subandean range from northern Argentina to northern Bolivia and is subdivided into eight formations and two groups (Padula and Reyes, 1960; Ahlfeld and Branisa, 1960; Ayaviri, 1972; Reyes, 1972). (Tab. I.)

Table I - Stratigraphic classification and nomenclature of Carboniferous rocks of Subandean Bolivia (Ayaviri, 1972)

\begin{tabular}{ll}
\hline Lower Mesozoic \\
: \\
Mandisconformity \\
San Telmo Fm. \\
Escarpment Fm. \\
\hline & Disconformity \\
& Taiguati Fm. \\
& Chorro Fm. \\
& Tarija Fm. \\
& Itacuamí Fm. \\
& Tupambi Fm. \\
& Itacua Fm. \\
& Unconformity \\
\hline
\end{tabular}

*Instituto de Geociências; Universidade de São Paulo, G.P. 20899, São Paulo (SP), Brasil **Universidade de Buenos Aires, Ciudad Universitaria, Nũnez, Pabellón 2, Buenos Aires, Argentina 
The scarcity of fossils and inconsistencies in previous identifications have led to controversy regarding the age of this sequence within the Late Paleozoic.

Previous references to marine fauna in the Taiguati Formation of Southern Subandean Bolivia are those of Catchcart (1926, in Arigos, 1945; Padula and Reyes, 1960) and Chamot (1960).

Fossils collected by Catchcart were identified by K. S. W. Palmer who listed Leipteria sp., Myalina sp., Sphenothus sp., Naiadites sp. and Ptycomphalina or Mourlonia sp. and considered as of Carboniferous age. Several tentatives by Bolivian geologists were unsuccesfull in relocating the fossiliferous outcrops along the Quebrada $n .^{\circ} 4$, Charagua Range, and the original collection was not available for study. Nevertheless, it seems that some of the species listed by Palmer coincide with taxa described herein.

Chamot (1960), on the other hand, listed Productus probably P. cora?, other "productids", orthoceratid cephalopods, gastropods, crinoids and stems of Cyclodendron leslii (mispelled leslei in the original), from a 2-3 m thick "coquinoid" accummulation in sandstones of the Taiguati Formation cropping out along the Parapeti river. He correlated this assemblage with that of the Copacabana Group and thus attributed a Permian age to the Taiguati Formation, interpreted as the basal unit of the Mandiyuti Group (Chamot, 1960, p. 206). To the pre-Taiguati section, which includes most of the diamictites in Subandean Bolivia (Machareti Group), Chamot assigned an Upper Carboniferous age. These ideas caused much debate and apparently never gained much support, initially because of contradictory stratigraphical and paleogeographical evidence (e.g., Suarez Roca, 1962; Schlatter \& Nederlof, 1966; Lohmann, 1970), and later, in view of the identification of Upper Carboniferous palynomorphs in the Taiguati Formation and overlying units (Schlater \& Nederlof, 1966; Ayaviri, 1972; Reyes, 1972).

In view of present available evidence (see below) we suspect that the species listed by Chamot really reffers to some Copacabana Group locality instead of Taiguati Formation.

Branisa (1965) and Reyes (1972) also mention briefly other findings of marine fossils by Ayaviri (1972, p. 57, Fig. 6) in the Taiguati or the San Telmo Formation in the Balapuca range of the southern Subandean area. Recently, a fossiliferous horizon in the upper part of the Taiguati Formation cropping out along the Parapeti River on the eastern flank of the Charagua Range, southern Subandean area, was discovered by YPFB geologists (Reyes, 1972). From this locality Lopez Murillo (1974) reported the productoid Levipustula levis Maxwell, thus indicating an Upper Carboniferous age for the Taiguati Formation.

In 1974, together with Messrs. Marcimio Lopez P., Rubén Lopez M. and Félix Jimenez M., of YPFB, one of us (A.C.R.C.) had the opportunity to briefly examine part of the Late Paleozoic section along the Parapeti River, at which time a fossiliferous sandstone bed was discovered in the upper part of the Taiguati Formation on the eastern flank of the Charagua range, apparently at the same stratigraphic level as the fossiliferous horizon reported by Lopez Murillo (1974; Marcimio Lopez, 1974, personal communication). The fossils, including bivalves and gastropods, occur in dense concentrations in a brick-red to bright marroon, medium-grained sandstone, a few decimeters thick cropping out along the right bank of the Parapeti River, a few kilometers east of Murillo's locality. The lithology of the fossiliferous bed and the mode of occurrence of the fossils suggest to us this may indeed correspond to Chamot's (1960, p. 207) locality.

A small collection of fossils from two localities along the Parapeti River, as well as gastropods from the Balapuca section (Ayaviri, 1972), are described in this report. Also included are short discussions on the affinities and age of the fauna and its bearing on the Late Paleozoic paleogeographic reconstruction of Subandean Bolivia. 
AFFINITIES AND AGE OF THE FAUNA The fossils examined in this study are from three localities in southern Subandean Bolivia (Fig. 1):

a) Balapuca section: fossiliferous, dark-red, coarse sandstone occurring a little above the middle part of the San Telmo(?) Formation and about $112 \mathrm{~m}$ below the contact with the Cangapi Formation (Cretaceous), cropping out along the Bermejo-Tarija road (see Ayaviri, 1972, p. 57, Fig. 6; YPFB Loc. RL-76). The fossils are interpreted by some Bolivian geologists as occurring within the Taiguati Formation (Lopez Murillo, 1976, personal communication).

b) Parapeti River section: fossiliferous, red sandstone and shale in the upper part the Taiguati Formation ( $80 \mathrm{~m}$ thick), about $20 \mathrm{~m}$ below the contact with the Escarpment Formation on the western flank of the Charagua anticline (see Chamot, 1960, p. 207; Lopez Murillo, 1974; YPFB Loc. RL-196A).

c) Parapeti River section: fossiliferous, dark-red sandstone and shale, about $40 \mathrm{~cm}$ thick, outcropping along the right bank of the Parapeti River, at the same stratigraphic position as in $b$ above, some $6 \mathrm{~km}$ upstream from San Antonio de Parapeti (YPFB Loc. V-74).

Species identified in the fauna are as follows:

Brachiopods

Levipustula levis Maxwell (Loc. b)

Bivalves

Cypricardinia(?) boliviana sp. nov. (Loc. c)

Limipecten cf. L. burnettensis Maxwell (Loc. b)

Stutchburia sp. (Loc. b)

Myonia sp. (Loc. b)

Gastropods

Mourlonia balapucense sp. nov. (Locs. a, b, c)

As pointed out before comparison of this with other collections previously identified from Subandean Bolivia cannot be made at this time; the following discussion is thus confined to the material collected from the three localities mentioned above. Fragmentary remains suggest the probable presence of other bivalves in the fauna from at least localities b and c. From the Balapuca area, only gastropods were available for study, although Ayaviri (1972) reports the occurrence of brachiopods and bivalves. Thus, the present evaluation is preliminary until such time as additional collecting and revision of reported fossils from the Bolivian Carboniferous fauna can be made.

Levipustula levis Maxwell is undoubtedly the most important component of the assemblage. This productoid brachiopod characterizes the Levipustula levis zone in eastern Australia (Campbell, 1961; Maxwell, 1964; MacKellar, 1965) and in the Central-Patagonian and Calingasta-Uspallata basins of Argentina (Amos, 1960; Amos and Rolleri, 1965; Amos et al., 1973).

Roberts et al. (1976) have recently discussed the age of the Levipustula levis zone in Australia. On basis of conodont (Crane, 1975, in Roberts et al., 1976) and cephalopod (Roberts, 1976) evidence the first occurrence of Levipustula levis in eastern Australia is now considered as Early Namurian. The brachiopod evidence, on the other hand, shows that the upper unit of the zone ranges into the Westphalian.

In the Central Patagonian basin of Argentina Levipustula levis seems to occur both associated and below strata with the cephalopods Wiedeyoceras argentinense (Miller and Furnish, 1958 = Anthracoceras? argentinense Miller \& Garner, 1953) and Eosianites sp. (Miller 
and Garner, 1953 = Glaphyrites sp., Gordon Jr., 1964), and is associated with Sueroceras chubutense? (Riccardi and Sabatini, $1975=$ Dolorthoceras chubutense Closs, 1967) in the upper part of the "Tepuel System" and the Las Salinas Formation (Gonzalez, 1972a; Riccardi \& Sabatini, 1975). Of these, Wiedeyoceras is known to occur in strata of Late Mississipian to Middle Pennsylvanian age in the U.S. The Argentinian taxon was compared to Early Pennsylvanian species of North America by Miller \& Garner (1953). The other fossils associated with Levipustula levis in the Central Patagonian basin were considered as indicative of a Late Carboniferous age (Amos et al., 1973). Moreover, Levipustula levis also occurs in the Calingasta-Uspallata basin of the Argentinian Precordillera associated with other brachiopods also interpreted as of Late Carboniferous age (Amos and Rolleri, 1965; Amos et al., 1973).

Cypricardinia(?) boliviana resembles specimens of several described and undescribed species from the Carboniferous and Permian of the Gondwana Province, but their true relationship is difficult to interpret due to the esually unsufficient documentation of the total morphologic variation of the Cypricardinia?

The pectinoid Limipecten burnettensis Maxwell is presently known only from the Upper Carboniferous Rands Formation of eastern Australia, where it is associated with Levipustula levis (Maxwell, 1964).

The other two bivalves from the Taiguati Formation are more difficult to assess due to the small number and poor preservation of available specimens. Myonia sp. resembles several Late Paleozoic species from Australia and South America (Runnegar, 1967; Rocha-Campos, 1970). The specimens of Stutchburia sp. are small and expanded posteriorly. Their association with Levipustula levis probably requires extension of the known range of the genus Stutchburia.

To date, gastropod specimens identified as Mourlonia are the only element common to the three localities investigated. They are interpreted as representing a new taxon.

Briefly, on the basis of available information, assignment of a Late Carboniferous age for the fauna seems reasonable. This fauna has obvious links with other Gondwana faunas at both the generic and specific levels. This age assignment for the Taiguati Formation is consistent with the unpublished palynological data mentioned by Ayaviri (1972), which also indicate Late Carboniferous (Pennsylvanian) age for the Mandyiuti Group. In South America, other assemblages containing Levipustula levis occur in the Gentral-Patagonian basin (Amos, 1960; Amos et al., 1973; Gonzalez, 1972a, b) and in the Calingasta-Uspallata basin of Argentina (Amos and Rolleri, 1965; Amos et al., 1973). (Fig. 1.)

PALEOGEOGRAPHIG IMPLICATIONS Many available paleogeographic reconstructions of the Subandean basin during the Carboniferous (e.g., Frakes and Crowell, 1969; Helwig, 1970, 1972; Amos, 1972; Reyes, 1972; Rocha-Campos, 1973) depict it as a SE-NW elongated, narrow depression (miogeosyncline foredeep, Helwig, 1972; Vicente, 1975), open towards the north and closed at its southern extremity in southern Bolivia and northern Argentina. The main elements of its tectonic framework include an elongated (N-S) positive element known as the Pampean system (Schlatter and Nederlof, 1966; = Pampean and Altiplano massives, Lohmann, 1970; = Pampean massif, Helwig, 1970, 1972; = Pampean nesocraton, Reyes, 1972) to the west; the Michicola high to the south (Reyes, 1972; = Chaco massif, Lohmann, 1970); and the Brazilian shield comprising the boundary to the east. The first two elements separate the Subandean basin from both the Altiplano basin to the west (Helwig, 1972; Reyes, 1972) and the Chaco- 


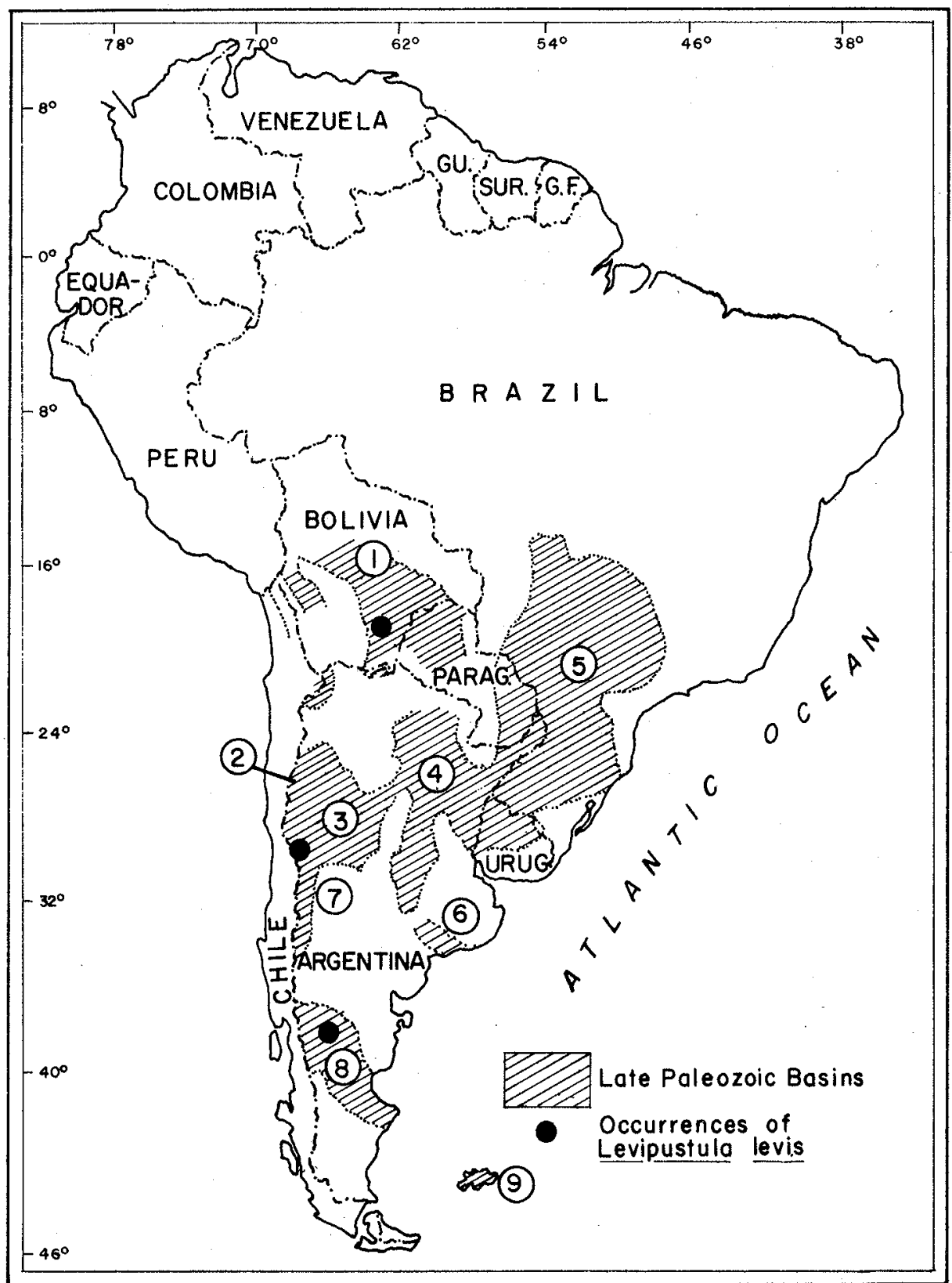

Figure 1 - Late Paleozoic basins of South America and known occurrences of faunas with Levipustula levis. Explanation: 1) Eastern Bolivian Basin; 2) Rio Blanco Basin; 3) Paganzo Basin; 4) Ghaco-Mesopotamian Basin; 5) Paraná Basin; 6) Sierras Australes; 7) Calingasta-Uspallata Basin; 8) Central-Patagonian Basin; 9) Malvinas (Falkland) islands. Sources various 
-Paraná (Amos, 1972) or Chaco-Mesopotamian basin (Padula and Mingramm, 1970) of Argentina.

The general facies of the Carboniferous sequence is descrided as mainly continental grading to paralic towards the Titicaca area (Harrington, 1955; Schlatter and Nederlof, 1966; Helwig, 1970) with a substancial contribution of sediments of glacial origin derived from western and eastern source areas (Schlatter and Nederlof, 1966; Lohmann, 1965, 1970; Frakes and Crowell, 1969) and which, at least in part, were transported by mass movement mechanisms (Frakes and Crowell, 1969). Other interpretations (Reyes, 1972; Ayaviri, 1972; Rodrigo, 1973) depict the facies as mainly marine, grading to partially paralic towards the Altiplano area.

The occurrence and affinities of the marine fauna in the Taiguati Formation, suggest the need for reinterpretation of the paleogeography of the area. Clearly, part of the sequence was deposited in a marine basin (see Fig. 1). However, the location of the marine pathway constitutes a major problem.

The possibility of a marine ingression from the north seems least probable in view of the interpretation of a paralic facies of the Gondwana sequence in the northern Altiplano area and because of the present lack of affinities between the studied fauna and marine Late Carboniferous faunas of the South American Tethyan province (e.g., Tarma Group of Peru; Chronic, 1953).

A sea connection between the southern Subandean area and the Argentinian Precordillera to the southwest would be possible only across the Pampean massif, which behaved as a positive element beginning in the Early Paleozoic (Vicente, 1975).

Alternatively, the sea could have ingressed from the southeast through the Paraguayan Chaco and the Chaco-Paraná or Chaco-Mesopotamian basin across the Michicola High. Reyes (1972) described this structural high as a "substable, positive, subdeformable element" which formed an erosional southern limit for the eastern Carboniferous basin (= Carboniferous belt, Helwig, 1972). The generalized isopach map presented by Schlatter and Nederlof (1966, p. 11, Fig. 7) shows Carboniferous sediments extending towards the southeast beneath the surface of the Chaco-Beni and Paraguayan Chaco. Ayaviri (1972, p. 53, Fig. 2) presents a slightly different version, but shows also a possible narrow extension of the Carboniferous sequence to the southeast between the Brazilian shield and a positive protuberance which seems to correspond to the Izozog high of Reyes (1972). Carboniferous strata correlatable to the Tupambi and Escarpment Formations of Subandean Bolivia are known to occur in the subsurface of Paraguayan Chaco (Eckel, 1959; Palmieri and Vera-Morinigo, undated). Facies and ages of the Late Paleozoic subsurface sequence of the Chaco-Mesopotamian basin of Argentina are not known in detail (Padula and Migramm, 1970). Thus, available information is insufficient to establish which of the last two possibilities is the more probable.

\section{SYSTEMATIC PALEONTOLOGY}

Genus LEVIPUSTULA Maxwell, 1951

Type-species: Levipustula levis Maxwell, 1951, by original designation. Levipustula levis Maxwell, 1951

Plate $1(1-5)$

Remarks: Most specimens examined are incomplete. Three internal moulds of the pedicular valves probably of young specimens are well preserved and together with several fragments of internal and external moulds of brachial valves show the main diagnostic features of Levipustula levis Maxwell. 
Dimensions $(\mathrm{mm})$ :

$\begin{array}{lllc} & & \text { Length } & \text { Width } \\ \text { GP/1E } 633 & \text { (pedicle valve) } & 16 & 21 \\ \text { GP/1E } 575 B \text { (pedicle valve) } & 13 & 15 \\ \text { GP/1E } 632 & \text { (pedicle valve) } & 14 \text { (inc.) } & 17\end{array}$

Material: Four internal moulds of ventral valves (GP/1E 575B, 632, 633, 638), four fragmentary external and internal moulds of brachial valves (GP/1E 634, 639, 642, 643), plus several other fragmentary specimens (GP/1E 635, 636, 637).

Distribution: Upper part of the Taiguati Formation, Parapeti River (Machareti Group), southern Subandean area, Bolivia (YPFB Loc. 196A).

\section{Genus LIMIPEGTEN Girty, 1904}

Type-species: Limipecten texanus Girty, 1904, by original designation. Limipecten cf. L. burnettensis Maxwell, 1964

\section{Plate 1 (6-7)}

Remarks: Available specimens are fragmentary and thus difficult to orient. General shape and ornamentation of probably left valves of the Bolivian species are closely comparable with those of Limipecten burnettensis Maxwell (1964, p. 14-15, Pl. 1, Figs. 14-17, P1. 2, Figs. 4-11). As shown by the more complete specimen, an internal mould of a left(?) valve, costae on the body of shell are irregular, with up to five costae per fascicle. The body is also concentrically crossed by several depressions which give it an undulating apperance in profile. Costae apparently increase in number mostly by intercalation, although a few bifurcations may also be noted. Part of the anterior auricle has at least eight costae crossed by numerous concentric lamellations.

Maxwell (1964, p. 14) points out that concentric lamellae project marginally from the shell surface, but we were unable to determine from his illustrations whether this occurs between or on costae (Newell, 1938). An abraded valve fragment of undeterminable orientation from Bolivia shows lamellae apparently projecting marginally on costae and towards the umbo in the interspaces and thus would differ from the typical Limipecten. The specimens from Bolivia are about half the size of specimens of $L$. burnettensis from Queensland illustrated by Maxwell (1964).

$$
\begin{array}{ccc}
\text { Dimensions (mm): } & \text { Length } & \text { Height } \\
\text { GP/1E 578A (left valve) } & 38 \text { (inc.) } & 40
\end{array}
$$

Material: Incomplete internal and external moulds of left(?) valve (GP/1E 578A; 579A, respectively); valve fragment of undeterminable orientation (GP/1E 578D).

Distribution: Upper part of the Taiguati Formation, Charagua Range, southern Subandean area, Bolivia (YPFB Loc. 196A).

\section{Genus STUTGHBURIA}

Type-species: Orthonota? costata Morris, 1845, by original designation. Stutchburia sp.

Plate $1(8-10)$

Remarks: The most complete specimen is an internal mould of left valve. It is relatively elongated and expanded posteriorly, giving a modioloid appearance to the shell. The 


\section{PLATE 1}
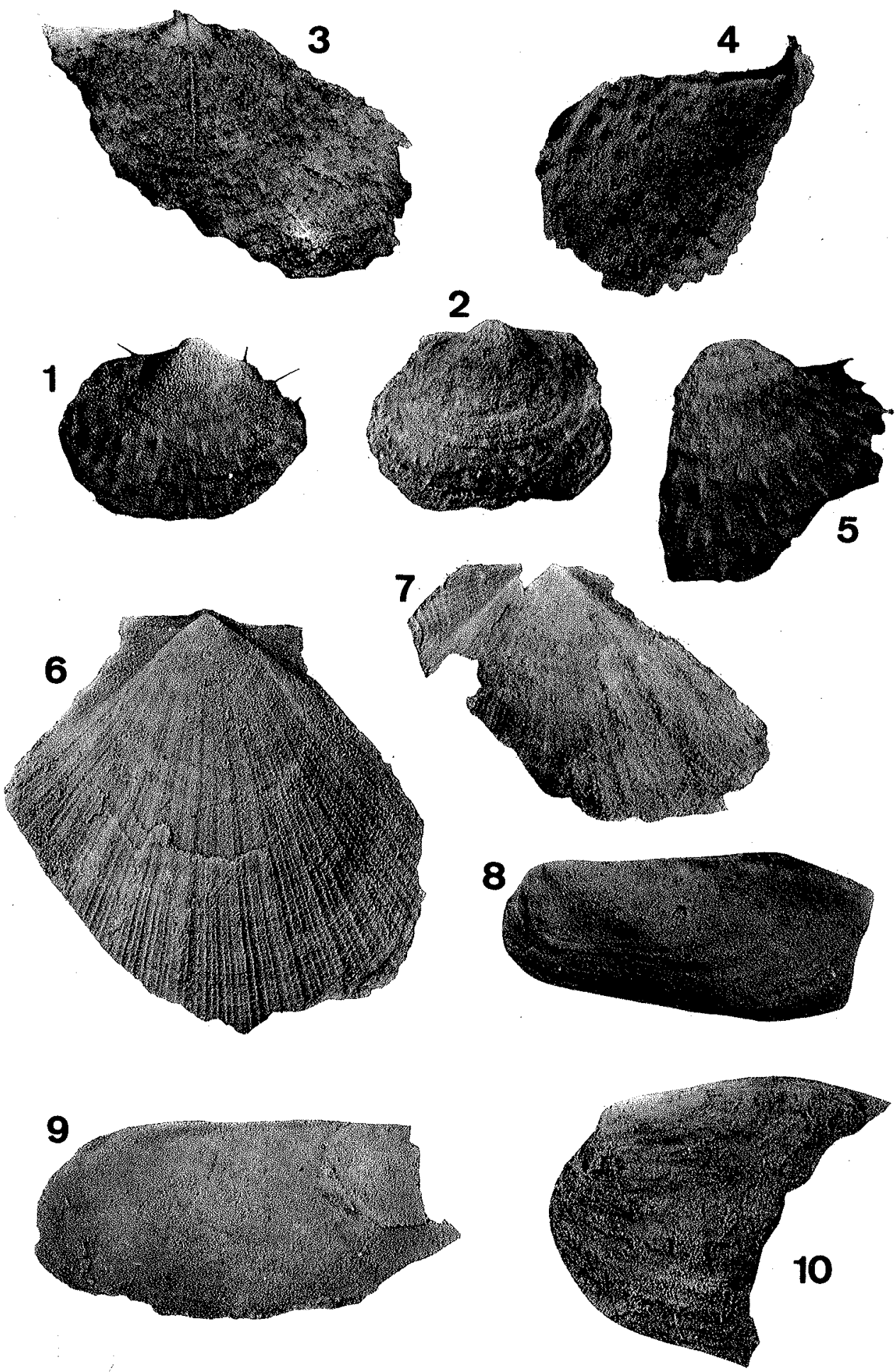


\section{PLATE 1}

\section{1-5: Levipustula cf. L. levis Maxwell, 1951}

(1) Internal mould of pedicle valve showing spine bases and spines, GP/1E 632A, upper part of the Taiguati Formation, Gharagua Range (YPFB Loc. 196A), X 2.3. (2) Internal mould of more complete pedicle valve, GP/1E 575B; same locality, X 2.2. (3) Latex cast of internal mould of brachial valve showing visceral disk and mid-ridge, GP/1E 634A; same locality, X 3. (4) Internal mould of brachial valve showing cardinal process, GP/1E 673; same locality, X 3.3. (5) Latex cast of external mould of pedicle valve showing spine basis, GP/1E 635; same locality, X 2.7.

6-7: Limipecten cf. L. burnettensis Maxwell, 1964

(6) "Internal" mould of left(?) valve showing ornamentation, GP/1E 578A; upper part of the Taiguati Formation, Charagua Range (YPFB Loc. 196A), X 1,6. (7) Latex cast of external mould of left(?) valve showing ornamentation of anterior auricle, GP/1E $579 \mathrm{~A}$; same locality, X 1.8.

8-10: Stutchburia sp.

(8) Internal mould of left valve, GP/1E 579B; upper part of the Taiguati Formation, Charagua Range (YPFB Loc. 196A) X 1.8. (9) Internal mould of right valve, GP/1E 579D; same locality, X 2. (10) Latex cast of external mould of left valve, GP/1E, same locality, X 2.3.

umbo is located anteriorly and not prominent. An obtuse umbonal ridge and an umbonal sinus are visible running obliquely from the umbo towards the posterior ventral margin. Dorsal and ventral margins are straight; the latter is slightly inflected where it is crossed by the umbonal sinus about one third of the length from anterior margin of valve. The posterior margin is probably rounded and slightly pointed at the intersection with the umbonal carina. A fragmentary external mould of a left valve shows a rounded anterior margin. Except for a slight indication on an internal mould of a right valve of a juvenile specimen, there is no clear sign of a scutcheon or a lunule.

The hinge shows no evidence of teeth. The anterior aductor is small, oval, elongated dorso-ventrally, bounded posteriorly by a very low ridge (buttress?).

The ornamentation consists of fine growth lines and occasional rugae; faint signs of radial ribbing appear in the area behind the ridge.

$\begin{array}{llc}\text { Dimensions (mm): } & & \text { Length } \\ & \text { Height } \\ \text { GP/1E 579B } & 32 \text { (inc.) } & 14 \\ \text { GP/1E 579D } & \text { (inc.) } & 15 \\ \text { GP/1E 579E } & 15 & 7\end{array}$

Material: Four fragmentary internal moulds (GP/1E 579B, D, E, and external mould (GP/1E 578) of left and right valves.

Distribution: Upper part of the Taiguati Formation, Charagua Range, Southern Subandean area, Bolivia (YPFB Loc. 196A).

Discussion: The general shape of the studied specimens is close to that of species included under Stutchburia Morris. Except for evidences on a probably juvenile specimen, we were unable to clearly identify a lunule or scutcheon (Dickins, 1963, p. 95-96; Newell, 1957; Moore, 1969, p. N 548). The presence of the umbonal ridge and sinus in the Bolivian species 
may also represent a difference, but these appear to occur in other Stutchburia, such as in S. hoskingae Dickins (1963, p. 96-98, Pl. 15). This Australian species, from the Lower Permian (Artinskian) Fossil Cliff Formation, resembles Stutchburia sp. in many respects except for the presence of posterior ribbing and lateral teeth in $S$. hoskingae. These features, however, are known to be intraspecifically variable among the Stutchburia (Newell, 1957; Dickins, 1963).

An undescribed species from the Late Paleozoic Santa Elena Formation in the Precordillera of Mendoza, Argentina (Rocha-Campos, 1970), is also similar to the Bolivian species but differs in the lesser elongation and posterior expansion and in the absence of a ridge and sulcus at least in larger specimens. In smaller specimens, however, an umbonal ridge and sulcus may be more visible.

\section{Genus MYONIA Dana, 1847}

Type-species: Myonia elongata Dana, 1847, by subsequent designation of Fletcher, 1932. Mrmia sp.

Plate $2(1-2)$

Remarks: In the collected material there are two fragmentary internal moulds which seem to fit the definition of Myonia.

One is a mould of a right valve of relatively small size for the genus. The shell is apparently elongated with a low rounded umbo situated more than one third of the shell length from the anterior margin. The anterior margin seems to be evenly rounded; part of the preserved dorsal posterior margin indicates that it is concave upward. The umbonal carina is well defined. This valve exhibits a relatively narrow umbonal sulcus which runs

1-2: Myonia sp.

PLATE 2

(1) Internal mould of right valve showing the carina, GP/1E 634A; upper part of the Taiguati Formation, Charagua Range (YPFB Loc. 196A), X 2. (2) Internal mould of left valve, GP/1E 575A; same locality,' X 2.

\section{3-8: Cypricardinia(?) boliviana sp. nov.}

(3) Paratype G, internal mould of left valve with parts of shell, showing anterior adductor and concentric lamellae, GP/1E 615; upper part of the Taiguati Formation, Gharagua Range (YPFB Loc. V-74), X 3. (4) Paratype B, right valve showing hinge, GP/1E 612; same locality, X 3.5. (5) Paratype A, internal mould of right valve showing lateral teeth, GP/1E 601; same locality, X 2.6. (6) Holotype, internal mould of left valve showing muscle scars, GP/1E 597; same locality, X 3. (7) Paratype $\mathrm{C}$, internal mould of right valve showing lateral teeth, GP/1E 610 , same locality, X 4 . (8) Paratype E, internal mould of right valve of larger specimen with parts of shell, showing ornamentation and umbo, GP/1E 609; same locality, X 2.3 .

\section{9-13: Mourlonia balapucense sp. nov.}

(9) Holotype showing selenizone and ornamentation, GP/1E 653, middle part of the San Telmo(?) Formation, Balapuca Range (YPFB Loc. RL-76), X 2. (10) Paratype A showing selenizone and ornamentation. GP/1E 652, same locality, X 2.7. (11) Paratype D, internal mould showing keeled selenizone, GP/1E 647, upper part of the Taiguati Formation, Charagua Range (YPFB Loc. 196-A), X 3.5. (12) Paratype G, internal mould, GP/1E 576, same locality, X 3.5. (13) Paratype B, internal mould, GP/1E 591, upper part of the Taiguati Formation, Charagua Range (YPFB Loc. V-74) 


\section{PLATE 2}
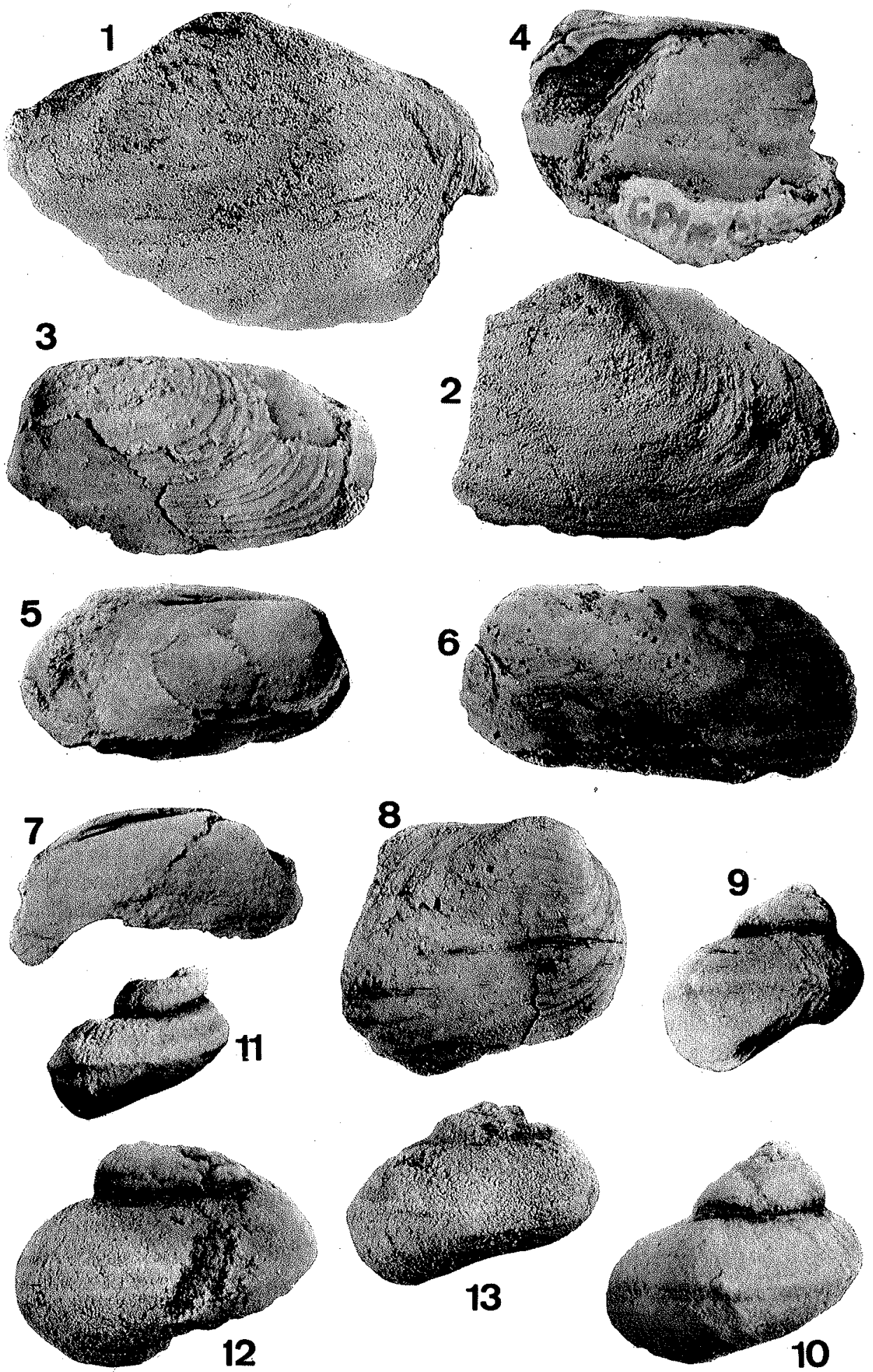
almost perpendicularly from umbo to the ventral margin. Hinge details are badly preserved, but the shell seems edentelous. A narrow scutcheon may be present.

Another specimen, an internal mould of the posterior part of a left valve, shows the carina extending as far as the posterior dorsal margin. The posterior margin is slightly pointed where intersected by the carina. Both valves are ornamented with fine growth lines. Internal features are not known. No measurements could be made due to fragmentary state of the examined specimens.

Material: Two fragmentary internal moulds of left and right valves (GP/1E 634A, 575A, respectively).

Distribution: Upper of the Taiguati Formation, Charagua Range, Southern Subandean area, Bolivia (YPFB Loc. 196A).

Discussion: The reconstructed general shape and the presence of an umbonal carina and a sulcus are sufficiently characteristic to justify the adopted generic assignment.

Myonia sp. from the Taiguati Formation is similar to several Upper Paleozoic species. Its general shape resembles Myonia carinata (Morris) and Myonia carinella Runnegar, both from the Permian of eastern Australia (Runnegar, 1967, Pl. 5, Fig. 20; Pl. 4, Fig. 10). If differs, however, from the former in having an umbonal sulcus and from the latter by its more distinct carina. Both Australian species are also larger.

Myonia sp. is also similar to an undescribed species from the Santa Elena Formation of the Precordillera of Mendoza, Argentina (Rocha-Campos, 1970), although the lateral sulcus may appear deeper in the Bolivian shell. This feature however, seems to vary in the Argentinian species, and examination of additional collection of Myonia sp. may minimize their differences.

\section{Genus GYPRICARDINIA Hall, 1859}

Type-species: Cypricardinia lamellosa Hall, 1859, by subsequent designation of Hall, 1885. Plate 2 (3-8)

Remarks: The doubtfull taxonomic status of Late Paleozoic species which have been referred to the Devonian genus Cypricardinia Hall has been previously discussed by Girty (1909, p. 446), Licharew (1931, in Newell, 1955), Newell (1955, p. 30), Campbell (1961, p. 469), and Dickins (1963, p. 99).

The discussion of Dickins (1963, p. 98) is also entirely pertinent to the Bolivian material. A few points, however, deserve further discussion. Well preserved internal moulds show the anterior adductor scar bounded posteriorly by a shallow and narrow sulcus that may correspond to a weak buttress. In most specimens having both valves, the dorsal margin of the left valve (umbo and cardinal area) is more prominent than the corresponding region of the right valve, which suggests inequivalvity. This is particularly true for the larger specimens, although some seem to have been sheared parallel to the commissure. A few inequivalve moulds, however, show no obvious sign of deformation. Slight elevation of the left umbo was also found in internal moulds of an undescribed species from the Middle Pennsylvanian Gerro Prieto Formation from the Amotape Mountains, Peru.

Cypricardinia(?) boliviana sp. nov.

Plate 2 (3-8)

Holotype: GP/1E 597, in the type collection, Departamento de Paleontologia e Estratigrafia, Universidade de São Paulo. 
Diagnosis: Shell possibly at least slightly inequivalve, elongated, modioloid. Anterior adductor bounded posteriorly by a shallow and narrow sulcus. Larger specimens with a distinct, rounded umbonal ridge and barely visible umbonal sinus.

Description: Shape highly variable. Internal moulds of smaller specimens tend to be oval to sub-rectangular, slightly expanded posteriorly. Larger specimens, including holotype, may be more modioloid, and expanded posteriorly.

Holotype is a bivalved shell with a subanterior umbo, slightly elevated above the hinge. Anterior margin rounded, concave in front of umbo. Dorsal margin is straight to slightly concave a little elevated with regard to that of right valve, rising up posteriorly; ventral margin straight, only slightly inflected at intersection with umbonal sinus; posterior margin oblique anteriorly, pointed at intersection with umbonal ridge. The anterior adductor scar is relatively large, oval and oriented with its longer axis inclined towards rear, bounded posteriorly and dorsally by a shallow and narrow groove.

Paratype A and G (internal moulds of bivalved specimens) show the oval adductor scar and circunscribing groove better, as well as possibly other small marks above the anterior adductor.

Paratype B, a right valve, shows two or three posteriorly oblique cardinal teeth, separated by sockets for two teeth in the left valve; impressions of two elongated lateral teeth in the left valve are visible in Paratypes A, D, E (internal moulds). Ligament groove elongates marginally and posteriorly from below umbo.

Paratypes $\mathrm{G}$ and $\mathrm{F}$ (internal moulds of left valves) show concentric ornamentation formed by fine growth lines and regularly spaced imbricated lamellae, crossed by fine, discontinuous radial ribs, the latter usually badly preserved on fragments of the shell.

\begin{tabular}{llll}
\multicolumn{1}{c}{ Dimensions $(\mathrm{mm})$ : } & Length & Height & \multicolumn{1}{c}{ Thickness } \\
Holotype GP/1E 597 & 19 & 9 & 8 (two valves) \\
Paratype A GP/1E 601 & 19 & 10 & 8 (two valves) \\
Paratype D GP/1E 610 & 11 & (inc.) & (inc.) \\
Paratype E GP/1E 611 & 12 & (inc.) & (inc.) \\
Paratype G GP/1E 613 & 19 (inc.) & 10 (inc.) & 10 (two valves)
\end{tabular}

Material: About 50 internal and external moulds, many of bivalved specimens, some with portions of the shell material (GP/1E 580-590, 597-631, 645).

Distribution: Upper part of the Taiguati Formation, Charagua Range, southern Subandean area, Bolivia (YPFB Loc. V-76).

Discussion: Cypricardinia(?) boliviana is the commnest species in the coquina bed of the Taiguati Formation, other fossils being rare. Parts of the bed are almost entirely made up of bivalved specimens of Cypricardinia(?) boliviana, mostly as moulds, but also including some with parts of the shell preserved.

As in other Late Paleozoic species of Cypricardinia(?), shape is variable. Larger shells, mostly internal moulds, tend to be more modioloid, with expanded rear and more visible posterior carina and sinus. Large specimens with parts of shell preserved show a more prominent and slightly inrolled umbo.

Certain specimens of the Bolivian form may thus be similar to other described species. Among these Cypricardinia(?) boliviana is close to? Cypricardinia sp. from the Carboniferous 
(Westphalian) Booral Formation of eastern Australia (Campbell, 1961, p. 469, Pl. 61, Figs. 6, 7). Except for the presence of a third lateral posterior tooth in the right valve, Campbell's description of the hinge of the Australian species coincides with that of $C$. (?) boliviana, although internal moulds of the former seem to be more expanded towards posterior part of shell (Pl. 61, Fig. 6) compared to Bolivian specimens of the same size.

Another similar species is C.? elegantula Dickins (1963, p. 98-99, Pl. 16, Figs. 10-19) from the Permian of Western Australia. The hinge exhibited in Pl. 16 is in general identical with that of C.(?) boliviana. However, all specimens of the Australian species are more modioloid, although the range of variation in shape may coincide in great part. According to Dickins (1963, p. 98) C.? elegantula is equivalve, a feature which would separate the two Gondwana species.

Cypricardinia? sp. and Cypricardinia? aff. elegantula Dickins, from the Las Salinas Formation in southern Argentina (Gonzalez, 1972b, p. 206-208, Pl. 3, Figs. 11, 12) differ from the Bolivia species in being more quadrate, although again in this case the entire range of shape is unknown. Gonzalez (1974, p. 254-255, Pl. 2, Figs. 8-9) illustrated internal and external moulds of a small specimen with the two valves together identified as Netschajewia Licharew, which might correspond to a Cypricardinia(?). His specimen is similar to small specimens of Cypricardinia(?) boliviana.

Internal moulds of larger specimens of an undescribed species from the Cerro Prieto Formation (Upper Carboniferous) of northern Peru are also closely comparable to specimens of C.(?) boliviana. The Peruvian species is large for the genus, but its range of variation in shape presently cannot be properly assessed.

\section{Genus MOURLONIA de Koninck, 1883}

Type-species: Helix carinatus Sowerby, 1812, by original designation. Mourlonia balapucense sp. nov.

Plate $2(9-13)$

Holotype: GP/1E 653 in type collection, Departamento de Paleontologia e Estratigrafia, Universidade de São Paulo.

Diagnosis: Shell apparently short; upper whorl surface moderately convex, slightly angular where it meets a narrow selenizone bounded by slightly raised spiral lirae; lower whorld surface evenly rounded; ornamentation formed by fine growth lines; spiral ornamentation weak.

Description: Shell turbiniform. Holotype and more complete specimens have four whorls. Sutures distinct and situated immediately below the selenizone, exposing only the upper, moderately convex surface of whorl; slightly angular at the narrow, depressed, selenizone with numerous lunulae, bordered by two slightly raised lirae. Lower surface of whorl homogeneously rounded. A small steinkern shows a raised selenizone bordered by two keels, but the specimen has been compressed dorso-ventrally. Protoconch is not preserved; base of shell anomphalous.

Growth lines, as exhibited by the holotype and paratype A, are regularly prosocline from suture, inclined at about $35-40^{\circ}$ from vertical, more incurved posteriorly above selenizone, opisthocline below the selenizone for a short distance, then turning to almost orthocline. Spiral ornamentation formed by fine, badly preserved lirae, generally more visible in the upper whorl surface. 
Dimensions: (mm)

Holotype GP/1E 653
Paratype A GP/1E 652
Paratype B GP/1E 591
Paratype G GP/1E 576
Paratype D GP/1E 647

$\begin{array}{rr}\text { Height } & \text { Width } \\ \text { (inc.) } & 15 \\ 12 \text { (inc.) } & 14 \text { (inc.) } \\ 7 \text { (inc.) } & 10 \text { (inc.) } \\ 8 \text { (inc.) } & 11 \text { (inc.) } \\ 6 \text { (inc.) } & 8 \text { (inc.) }\end{array}$

Apical angle
$\pm 90^{\circ}$
$\pm 82^{\circ}$
$\pm 85^{\circ}$
$\pm 88^{\circ}$
$\pm 70^{\circ}$

Spiral angle

Material: About 15 shells and internal and external moulds.

Distribution: Upper part of the Taiguati Formation, Gharagua Range, southern Subandean area (YPFB Locs. 196A and V-74), and at about the middle of the San Telmo(?) Formation, Balapuca Range, southern Subandean area, Bolivia (YPFB Loc. RL-76).

Discussion: To date, this is the most widespread species in Subandean Bolivia, occurring in the three fossiliferous localities studied.

The weak spiral ornamentation of Mourlonia balapucense, together with its other characters, separate it from other described species. Similar ornamentation may be present in Mourlonia minuta Yochelson \& Dutro (1960, p. 136, Pl. 13, Figs. 4-5) from the Upper Mississipian of Alaska. This species, however, has a wider selenizone and a more globose whorl profile.

According to Dickins' (1963, p. 117-118) taxonomic scheme for the pleurotomariid gastropods, the Bolivian species would fall in the subgenus Mourlonia (Mourlonia), even though all described species in the Permian of Australia seem to exhibit a stronger spiral ornamentation.

Acknowledgements The senior author is indebted to Engrs. Jaime Oblitas G. and Carlos Salinas E., of the Gerencia de Exploración, Yacimientos Petroliferos Fiscales Bolivianos, for facilities provided during field work in Bolivia and for authorization to publish this report; to Engrs. Marcimio Lopez P., Rubén Lopez M. and Félix Jimenez M. (YPFB), for their assistance in the field. Dr. Thomas R. Fairchild offered valuable suggestions for the improvement of this report. This paper is a contribution of the IGCP Project Upper Paleozoic of South America (Proj. n. ${ }^{\circ} 42$ ), which has the financial support of CNPq (Proc. 2222.0219/75).

\section{REFERENCES}

AHLFELD, F. and BRANISA, L. $-1960-$ Geologia de Bolívia, $2^{\text {nd }}$ Ed., Inst. Boliv. Petr., La Paz

AMOS, A. J. - 1960 - Algunos Chonetacea y Productacea del Carbonífero Inferior del Sistema de Tepuel, Provincia de Chubut. Rev. Asoc. Geol. Argentina, 15 (1-2): 81-107

AMOS, A. J. - 1972 - Las cuencas Carbónicas y Permicas de Argentina. An. Acad. Bras. Ciênc., 44 (Suplemento): 21-36

AMOS, A.J. and ROLLERI, E. O. - 1965 - El Carbónico marino en el valle Calingasta-Uspallata. Bol. Inf. Petroleras, N. ${ }^{\circ}$ 368: 1.23

AMOS, A. J.; ANTELO, B.; GONZALEZ, G. R.; MARINELARENA, M. P. DE, and SABATINI, N. - 1973 - Sintesis sobre el conocimiento biostratigrafico del Carbónico y Permico de Argentina. Actas 5. Congr. Geol. Argentino, 3: 3-20

ARIGOS, L. E. - 1945 - Estudio estratigráfico y tectónico de una sección de la Sierra de Aguarague, entre Quebrada Jocuy y Quebrada Tres Quebradas. Ph. D. Thesis, Univ. La Plata, La Plata, Argentina (unpublished) 
AYAVIRI, A. - 1972 - El Sistema Carbonico en el sureste Boliviano. An. Acad. Bras. Ciênc., 44 (Suplemento): $51-60$

BRANISA, L. - 1965 - Los fosiles guias de Bolivia I. Paleozóico. Serv. Geol. Bolivia, Bol., N. ${ }^{\circ} 6$ CAMPBELL, K. S. W. - 1961 - Carboniferous fossils from the Kuttung rocks of New South Wales. Palacontology, $\mathbf{A}(3): 428-474$

CHAMOT, G. A. - 1960 - Fossiles marins dans le Gondwanien de Bolivie. Ecl. Geol. Helvetiae, 53(1): 205-207

CHRONIC, J. - 1953 - Invertebrate Paleontology (excepting fusulinids and corals). In N. D. Newell, J. Chronic and T. G. Roberts, Upper Paleozoic of Peru, Geol. Soc. Amer., Mem., N. 58

CLOSS, D. - 1967 - Orthocone cephalopods from the Upper Carboniferous of Argentina and Uruguay. Ameghiniana, 5(3): 123-129

DICKINS, J. M. - 1963 - Permian pelecypods and gastropods from Western Australia. Bur. Miner. Resour., Geol. and Geophys., Bull., N. ${ }^{\circ} 63$

ECKEL, E. B. - 1959 - Geology and mineral resources of Paraguay. Geol. Surv. Prof. Paper, N. ${ }^{\circ} 327$

FRAKES, L. A. and CROWELL, J. G. - 1969 - Late Paleozoic glaciation: I. South America. Geol. Soc. Amer. Bull., 80(6): $1007-1042$

GIRTY, G. H. - 1909 - Paleontology of the Manzano Group of the Rio Grande Valley, New Mexico. U.S. Geol. Surv., Bull., N. ${ }^{\circ} 389$

GONZALEZ, C. R. - 1972(a) - La Formación Las Salinas, Paleozoico Superior de Chubut (Republica Argentina), Parte I. Estratigrafia y ambientes de sedimentación. Rev. Asoc. Geol. Argentina, 27: 95-115

GONZALEZ, C. R. - 1972(b) - La Formación Las Salinas, Paleozoico Superior de Chubut (Republica Argentina), Parte II. Bivalvia: Taxinomia y paleoecologia. Rev. Asoc. Geol. Argentina, 27: 180-205

GONZALEZ, C. R. - 1974 - Bivalvos del Permico Inferior de Chubut, Argentina. Acta Geol. Lilloana, 12(13): 231-274

GORDON, Jr., M. - 1964 - Carboniferous cephalopods of Arkansas. U.S. Geol. Surv., Prof. Paper, N. ${ }^{\circ} 460$

HARRINGTON, H. J. - 1955 - Paleogeographic development of South America. Amer. Assoc. Petr. Geol., Bull., 46(10): 1 773-1 814

HELWIG, J. - 1970 - Stratigraphy, sedimentation, paleogeography and paleoclimates of Carboniferous ("Gondwana") and Permian of Bolivia. Amer. Ass. Petrol. Geol., Bull., 56(6): 1 008-1 033

HELWIG, J. - 1972 - Late Paleozoic stratigraphy and tectonics of the Central Andes. An. Acad. Bras. Ciênc., 44 (Suplemento): 161-171

LOHMANN, H. H. - 1965 - Paläozoische vereisungen in Bolivian. Geol. Rundschau, 54(1): 161-165

LOHMANN, H. H. - 1970 - Outline of tectonic history of Bolivian Andes. Amer. Assoc. Petr. Geol., Bull., 54(5): 735-757

LOPEZ MURILLO, R. D. - 1974 - Gomunicación preliminar acerca de la fauna Carbónica de la Formación Taiguati de la Serrania de Charagua. IV Conv. Nac. Geol., Resumenes: 11

McKELLAR, R. G. - 1965 - An Upper Carboniferous brachiopod fauna from the Monto District, Queensland. Geol. Surv. Queensl. Publ., N. ${ }^{\circ} 328$, Pal. Papers, N. ${ }^{\circ}$

MAXWELL, W. G. H. - 1951 - Upper Devonian and Middle Carboniferous brachiopods of Queensland. Pap. Dep. Geol. Univ. Qd., 3(14): 1-27

MAXWELL, W. G. H. - 1964 - The geology of the Yarrol region, Part I. Biostratigraphy. Univ. Queensl., Papers 5(9)

MILLER, A. K. and GARNER, H.F. - 1953 - Upper Carboniferous goniatites from Argentina. Jour. Paleon., 27(6): 821-823

MILLER, A. K. and FURNISH, W. M. - 1958 - The Goniate genus Anthracoceras Jour. Paleont., 32(4): $684-686$

MOORE, R. G. (Ed.) - 1969 - Treatise on Invertebrate Paleontology, Part N, 1, Mollusca 6 
NEWELL, N. D. - 1938 - Late Paleozoic pelecypods Pectinacea. Bull. State Geol. Surv. Kansas, $\mathrm{N} .^{\circ} 10$

NEWELL, N. D. - 1955 - Permian pelecypods of East Greenland. Medd. 110(4)

NEWELL, N. D. - 1957 - Notes on certain primitive heterodont pelecypods. Am. Mus. Novitates, N. ${ }^{0} 1893$

PADULA, E. L. and REYES, F. C. - 1960 - Contribución al lexico estratigrafico de las Sierras Subandinas. Yac. Petr. Fisc. Bolivianos, Bol. Tecn. 2(9): 9-66

PADULA, E. L. and MINGRAMM, A. - 1970 - Subsurface Carboniferous beds of the Chaco-Mesopotamian region, Argentina and their relatives in Uruguay and Paraguay: Gondwana Stratigraphy, IUGS Symposium, Buenos Aires: 1 025-1 040

PALMIERI, J. H. and VERA MORINIGO, G. - undated - Interpretación de los trabajos de exploración petrolifera realizados en el Chaco Paraguayo. Un. Nac. Asunción, Inst. Cien., Publ. S ${ }^{\text {er }}$ D, Informes Tecnicos, N. ${ }^{0}=12$

REYES, F. C. - 1972 - On the Carboniferous and Permian of Bolivia and northwest Argentina. An. Acad. Bras. Ciênc., 44 (Suplemento): 261-277

RICCARDI, A. C. and SABATINI, N. - 1975 - Cephalopoda from the Carboniferous of Argentina. Palaontology, 18: 117-136

ROBERTS, J., HUNT, J. W. \& THOMPSON, D. M. - 1976 - Late Carboniferous marine invertebrate zones of eastern Australia. Alcheringa, 1: 197-225

ROBERTS, J. - 1976 - Carboniferous chonetacean and productacean brachiopods from eastern Australia. J. Geol. Soc. Aust., 22: 1-32

ROCHA-CAMPOS, A. G. - 1970 - Upper Paleozoic bivalves and gastropods of Brazil and Argentina: a review. In S. H. Haughton (Ed.), Proc. \& Papers, 2nd Gondwana Symposium, S. Africa: 605-512, CSIR, Pretoria

ROCHA-CAMPOS, A. C. - 1973 - Upper Paleozoic and Lower Mesozoic paleogeography, and paleoclimatological and tectonic events in South America. In A. Logan (Ed.), The Permian and Triassic Systems and its mutual boundary: 398-424, Can. Soc. Petr. Geol., Calgary

RODRIGO, L. A. - 1973 - Sedimentologia del Grupo Machareti, Sección Angosto del Rio Pilcomayo, Departamento de Tarija. Soc. Geol. Bol., An. III Conv. Nac. Geol. Bol., N. 20: 199-230

RUNNEGAR, B. - 1967 - Desmodont bivalves from the Permian of Eastern Australia. Bur. Min. Resour., Geol. \& Geophys., Bull., N. ${ }^{\circ} 96$

SGHLATTER, L. E. and NEDERLOF, M. H. - 1966 - Bosquejo de la geologia y paleogeografia de Bolívia. Serv. Geol. Bolivia, N. ${ }^{\circ} 8: 1-49$

SUAREZ ROGA, H. - 1962 - Estratigrafia del Rio Tunal. Petr. Boliviano, 4(4): 32-34

VICENTE, J. G. - 1975 - Essai d'organization paléogéographique et structurale du Paléozoique des Andes meridionales. Geol. Rundschau, 64(2): 343-394

YOCHELSON, E. L. and DUTRO, Jr. J. T. - 1960 - Late Paleozoic Gastropods from Northern Alaska. U.S. Geol. Surv., Prof, Paper, N.³34-D 